\title{
Clone library analysis reveals an unusual composition and strong habitat partitioning of pelagic bacterial communities in Lake Tanganyika
}

\author{
Aaike De Wever ${ }^{1, *}$, Katleen Van der Gucht ${ }^{1}$, Koenraad Muylaert ${ }^{2}$, Sylvie Cousin $^{1}$, \\ Wim Vyverman ${ }^{1}$
}

${ }^{1}$ Ghent University, Department of Biology, Section of Protistology and Aquatic Ecology, Krijgslaan 281 S8, 9000 Ghent, Belgium

${ }^{2}$ K. U. Leuven-Campus Kortrijk, E. Sabbelaan 53, 8500 Kortrijk, Belgium

\begin{abstract}
The phylogenetic composition of bacterioplankton communities in Lake Tanganyika was studied by sequencing 16S rRNA gene clones. Four clone libraries were constructed from oxic epilimnion and anoxic hypolimnion samples collected during the dry season of 2002 in the northern and southern basins. Clone library analysis revealed a bacterial community composition (BCC) differing from previously studied freshwater systems and clear differences between both epi- and hypolimnion and the northern and southern basins. We detected few representatives of the Actinobacteria, Bacteroidetes, Cyanobacteria, and Alpha- and Betaproteobacteria commonly found in freshwater environments in temperate and cold regions, but observed a remarkably high number of clones belonging to Chloroflexi and Gammaproteobacteria. This was especially the case in the hypolimnion, but also in the epilimnion in the south of the lake, which suggests that the BCC may be influenced by seasonal upwelling. In total, nearly half of the detected operational taxonomical units were not closely related to bacteria previously observed in freshwater environments. Even in the epilimnetic clone libraries, genotypes commonly reported from oxic freshwater environments (e.g. ACK4, LD12, Sta2-30) were rare or absent.
\end{abstract}

KEY WORDS: Bacterial community composition · Clone library · Lake Tanganyika · Freshwater • Tropical lake

\section{INTRODUCTION}

Despite the introduction of culture-independent methods for mapping bacterial community composition (BCC) more than a decade ago, BCC in freshwater ecosystems has still only been studied to a limited extent. Bacterial communities have been investigated in different types of freshwater ecosystems, covering a range of oligotrophic crater lakes (Urbach et al. 2001), deep stratified lakes (Konopka et al. 1999), eutrophic shallow lakes (Zwart et al. 2002, Van der Gucht et al. 2005), humic polar lakes (Bahr et al. 1996) and rivers (Crump et al. 1999). Most of these studies, however, were carried out in temperate to cold regions in the northern hemisphere. Studies from tropical lakes are scarce and are often limited to unusual environments like hot springs and soda lakes or focus only on selected bacterial clades (e.g. Hahn 2003). The world's largest lakes are also underrepresented in studies of BCC. Of the 10 largest lakes by volume, BCC has to our knowledge only been studied in Lake Baikal (e.g. Bel'kova et al. 2003) and during our denaturing gradient gel electrophoresis (DGGE) study on Lake Tanganyika (De Wever et al. 2005). Although a DGGE study by Konopka et al. (1999) highlighted the contrast between oxic and anoxic 
samples in a series of thermal stratified lakes in northeastern Indiana, USA, studies on the BCC in anoxic hypolimnia or monimolimnia are also scarce. In a study based on the construction of clone libraries in the meromictic Lake Cadagno, Switzerland, the authors detected a high contribution of Gammaproteobacteria (mainly belonging to the phototrophic Chromatiaceae) near the oxic-anoxic boundary (Bosshard et al. 2000).

From the studies on BCC in freshwater environments, a fairly restricted set of genotype clusters typical for freshwater environments seems to emerge (Hiorns et al. 1997, Glöckner et al. 2000, Zwart et al. 2002, Lindström et al. 2005). This suggests the existence of typical freshwater clusters of bacteria that evolved in freshwater environments and were not merely 'transported' from soil. Recently, Eiler \& Bertilsson (2004) detected some new freshwater clusters in Swedish lakes, presumably associated with cyanobacterial blooms. Genotypes found in freshwater, but diverging from the typical freshwater clusters often originate from very peculiar habitats such as hot springs, activated sludge, aquifers and rice fields. The geographic range of the studies carried out so far precludes conclusions on whether these typical freshwater clusters have a global distribution or are mainly restricted to temperate regions. More studies including freshwater ecosystems from tropical regions and from the southern hemisphere are needed to determine whether the same clusters of freshwater bacteria occur everywhere or whether regional differences exist. Although several studies have suggested that most micro-organisms have a global distribution, others indicate that some micro-organisms may have a more restricted distribution (e.g. see discussion in Whitfield 2005).

Tropical Lake Tanganyika is the deepest African rift lake (maximum depth of $1470 \mathrm{~m}$ ). It is permanently temperature-stratified, oxygen is absent below a depth of $200 \mathrm{~m}$ and no light penetrates up to this depth. This huge volume of anoxic water, which forms the largest in any freshwater lake in the world, is characterized by hydrogen sulfide $\left(\mathrm{H}_{2} \mathrm{~S}\right)$, ammonia $\left(\mathrm{NH}_{3}-\mathrm{N}\right)$ and phosphate $\left(\mathrm{PO}_{4}-\mathrm{P}\right)$ concentrations of around 1.0, 0.5 and $0.2 \mathrm{mg} \mathrm{l}^{-1}$, respectively, at $500 \mathrm{~m}$ and mean bottom water concentrations of methane $\left(\mathrm{CH}_{4}\right)$ of around 3.4 and $2.0 \mathrm{mg} \mathrm{l}^{-1}$, respectively, in the northern and southern basins (Edmond et al. 1993). This ancient lake harbours a high diversity and has a high degree of endemism of various metazoa including cichlid fishes, snails and crabs. Recently we investigated the vertical and horizontal changes in BCC in Lake Tanganyika using 16 rDNA DGGE analysis (De Wever et al. 2005). This study highlighted differences between the oxic epilimnion and anoxic hypolimnion and between the northern and southern basins. These latitudinal differences in BCC were associated with upwelling of nutrient-rich deep water in the south of the lake. While this DGGE study revealed detailed information on the spatial distribution of bacterial genotypes in the lake, it lacked resolution on the taxonomy of the genotypes and the total diversity of the bacterial communities. To identify the genotypes in Lake Tanganyika with higher accuracy and investigate the diversity of the bacterial communities in the lake more exhaustively, we constructed 16S rDNA clone libraries from 4 contrasting locations: epilimnetic and hypolimnetic samples from both the northern and the southern basins.

\section{MATERIALS AND METHODS}

Study site. Lake Tanganyika in the East African rift valley is surrounded by the countries Burundi, Tanzania, Zambia and Democratic Republic of Congo. The lake region is characterized by 2 main seasons: the wet season and the dry season. During the dry season (from May or June to September or October) southeastern monsoon winds cause a transport of warmer surface water to the north, which results in upwelling of colder nutrient-rich water in the south of the lake and internal waves periodically bringing water richer in nutrients higher up in the water column. The intensity of these internal waves decreases towards the end of the rainy season.

For the present study, samples were collected during the dry season of 2002 in the epi- and hypolimnion in the north and south of the lake. Data obtained during this period (De Wever et al. 2005) exhibited a clear difference in water column stratification at the northern and southern sites. The temperature and oxygen profiles demonstrated the lower stability in the south during upwelling and the absence of oxygen below $200 \mathrm{~m}$. This upwelling also resulted in higher nitrate $(0.25$ to $\left.0.44 \mathrm{mg} \mathrm{l}^{-1} \mathrm{NO}_{3}-\mathrm{N}\right)$ and soluble reactive phosphorus ( 0.08 to $0.16 \mathrm{mg} \mathrm{l}^{-1} \mathrm{SRP}$ ) concentrations in the south of the lake. Conductivity (666 to $683 \mu \mathrm{S} \mathrm{cm}{ }^{-1}$ ) and $\mathrm{pH}$ (8.55 to 8.99) were slightly higher in the epilimnion in the north of the lake. During a 3 yr monitoring study at 2 stations, the photic depth ranged from 14 to $65 \mathrm{~m}$ (De Wever et al. 2007). Bacterial densities were highest in the epilimnion in the south $\left(3.1 \times 10^{6}\right.$ vs. $1.9 \times 10^{6}$ cells $\mathrm{ml}^{-1}$ in the north) and were similar in the hypolimnion of both basins $\left(0.30 \times 10^{6}\right.$ to $0.31 \times 10^{6}$ cells ml $\left.^{-1}\right)$.

Sampling. Sampling was performed along a north-south transect on Lake Tanganyika during the dry season of 2002 (10 to 14 July) and was part of a more extensive sampling campaign for a DGGE study on BCC (De Wever et al. 2005). The samples for 
genetic analysis were collected at 4 sites along this transect using Hydrobios (5 l) or Go-Flo (up to 12 l) sampling bottles. The epilimnion samples were collected from a depth of $20 \mathrm{~m}$ (Sites TK2 and TK9, respectively, in the northern and the southern basin). For the hypolimnion samples equal volumes collected from 500 and $600 \mathrm{~m}$ were pooled (Sites TK1 and TK8). The water samples for genetic analysis were prefiltered with a $5 \mu \mathrm{m}$ polycarbonate membrane to sample only free-living bacteria. The filtrate was then passed through a $0.22 \mu \mathrm{m}$ membrane filter; filtration of sample water was stopped after clogging of the filter (typically around 4 l). The filters were folded, wrapped in aluminum foil and stored frozen.

DNA extraction and PCR. Genomic DNA from the natural bacterial communities was extracted following the protocol described by Zwart et al. (1998b), which includes the bead-beating method concomitant with phenol extraction and ethanol precipitation. After extraction, the DNA was purified on a Wizard column (Promega) according to the manufacturer's recommendations. The nearly complete $16 \mathrm{~S}$ rRNA gene was amplified with the primers 27F (5'-AGAGTTTGATC MTGGCTCAG-3') and 1492R (5'-GRTACCTTGTTACGACTT-3'), which are specific for the domain Bacteria (Lane 1991). PCR was performed using the following reaction mixes: $5 \mu$ l of template DNA, each primer at a concentration of $0.5 \mu \mathrm{M}$, each deoxynucleoside triphosphate at a concentration of $200 \mu \mathrm{M}, 1.5 \mathrm{mM}$ $\mathrm{MgCl}_{2}, 20 \mathrm{ng}$ of bovine serum albumin, $5 \mu \mathrm{l}$ of $10 \mathrm{X}$ PCR buffer (100 mM Tris-HCl, pH 9; $500 \mathrm{mM} \mathrm{KCl),} \mathrm{and}$ $2.5 \mathrm{U}$ of Taq DNA polymerase (AmpliTaq, PerkinElmer), adjusted to a final volume of $50 \mu \mathrm{l}$ with sterile water (Sigma). PCR amplification was performed with a Genius temperature cycler using the following conditions: 3 min incubation at $94^{\circ} \mathrm{C}$ followed by 25 cycles consisting of denaturation at $94^{\circ} \mathrm{C}$ for $1 \mathrm{~min}$, annealing at $55^{\circ} \mathrm{C}$, extension at $72^{\circ} \mathrm{C}$ for $2 \mathrm{~min}$ and final extension at $72^{\circ} \mathrm{C}$ for $10 \mathrm{~min}$. The PCR products were quantified by analyzing $5 \mu \mathrm{l}$ of product on $1 \%(\mathrm{w} / \mathrm{v})$ agarose gels, staining with ethidium bromide and comparing with a molecular weight marker (Smartladder, Eurogentec).

Clone library construction. Equal amounts of DNA obtained with primers $27 \mathrm{~F}$ and $1492 \mathrm{R}$ were purified using the QIAquick PCR purification kit (Qiagen), ligated into pGEM-T Easy Vectors (Promega) and transformed into high efficiency competent Escherichia coli JM109 cells. The transformed cells were plated on Luria-Bertani (LB) plates containing $20 \mathrm{\mu g}^{-1}$ ampicillin, $20 \mathrm{\mu g}^{-1}$ of X-Gal (5-bromo-4-chloro-3-indolyl- $\beta$ D-galactopyranoside, $50 \mathrm{mg} \mathrm{ml}^{-1}$ ) and $5 \mu \mathrm{g} \mathrm{l}^{-1}$ of IPTG (isopropyl- $\beta$-D-thiogalactopyranoside, $100 \mu \mathrm{M}$ ) as recommended by the manufacturer, and incubated overnight at $37^{\circ} \mathrm{C}$. White recombinants were picked and grown overnight in ampicillin-supplemented liquid medium (Luria-Bertani Broth). Clones were screened by DGGE analysis as described in De Wever et al. (2005). This allowed us to define classes of bands at the same position corresponding to clones containing (presumably) the same inserts. One (or occasionally 2 to 4 ) representative of each band class was then chosen for sequencing. These band classes were used as operational taxonomical units (OTUs). The sequences belonging to the same band class had a sequence divergence of less than $1 \%$. Plasmids were isolated and purified from each clone culture with a High Pure plasmid isolation kit (Boehringer). Initial sequencing was performed with the ABI-Prism sequencing kit (PE-Biosystems) using the primer R519 and an automated sequencer (ABI-Prism 377). To obtain nearly complete sequences we used the primer R339 (ACTGCTGCCTCCCGTAGGAG), F358 (CTC CTACGGGAGGCAGCAGT), F519 (GTATTACCGCG GCTGCTG), F536 (CAGCAGCCGCGGTAA TAC), F926 (AACTCAAAGGAATTGACGG), R1093 (GTTG CGCTCGTTGCGGGACT) and F1241 (AGTCCCGC AACGAGCGCAAC) (Edwards et al. 1989) and assembled the sequences in Bionumerics. We obtained sequences of between 1414 and 1427 bp long, except for TK-SH8 and TK-SH19, which were, respectively, 475 and $1390 \mathrm{bp}$. These sequences were inserted in the trees using the ARB parsimony option and indicated as 'partial' on the phylogenetic trees.

Data analysis and phylogenetic tree construction. The presence of presumable chimera sequences was checked prior to further analysis using the Chimera_ check program (http://35.8.164.52/cgis/chimera.cgi? $\mathrm{su}=\mathrm{SSU})$. The Chao1 estimator was calculated using $S=S_{\text {obs }}+\left(a^{2} / 2 b\right)$, where $S$ is the Chao1 estimator, $S_{\text {obs }}$ is the observed number of OTUs, $a$ is the number of singletons and $b$ is the number of doubletons (Chao 1984). Good's coverage estimator was calculated as $C=$ $n_{1} / N$, where $n_{1}$ is the number of OTUs appearing only once and $N$ is the library size (Good 1953). Rarefaction analysis was performed with the software package PRIMER 5.

A GenBank BLAST search (Altschul et al. 1997) was performed for each of our sequences to identify sequences with a high similarity. These sequences with high similarity, representatives of typical freshwater clusters and sequenced clones were aligned in ARB within the SSU database maintained by Ludwig et al. (2004) for Escherichia coli position 8 to 1492 using the fast aligner option and manually corrected using secondary structure.

Phylogenetic analyses were performed with ARB (Ludwig et al. 2004). Trees were constructed using maximum likelihood (Felsenstein 1981), with Thermococcus acidaminovorans (Y15935) as an outgroup. Robustness of tree topology was explored using maxi- 
mum parsimony with 100 bootstrap replications and neighbour-joining with 1000 bootstrap replications (Saitou \& Nei 1987). Group names were obtained from the SSU database in ARB. To verify the assignment of sequences to the typical freshwater clusters, we evaluated within and between group distances.

Nucleotide sequence accession numbers. All $16 \mathrm{~S}$ rDNA sequences described in this study were submitted to GenBank under accession numbers DQ463691 to DQ463726, DQ463728 to DQ463743 and DQ995294 to DQ995296.

\section{RESULTS}

A total of 598 clones were screened, with each of the 4 individual libraries containing between 129 and 173 clones (Table 1). Although the Chao1 and Good's estimators suggested a fairly good coverage of the bacterial diversity (Table 1), the species accumulation curves for the 4 clone libraries did not reach a plateau (Fig. 1). The clones belonged to 63 DGGE OTUs. Two

Table 1. Number of clones and OTUs in the samples. $\mathrm{NH}=$ north hypolimnion, $\mathrm{NE}=$ north epilimnion, $\mathrm{SH}=$ south hypolimnion, $\mathrm{SE}=$ south epilimnion

\begin{tabular}{|lccccc|}
\hline & NH & NE & SH & SE & Sum \\
\hline Number of clones & 129 & 160 & 136 & 173 & 598 \\
Number of OTUs & 38 & 31 & 45 & 36 & 61 \\
Chao1 estimator & 58 & 72 & 58 & 45 & 81 \\
Good's coverage estimator & 0.91 & 0.85 & 0.90 & 0.90 & 0.98 \\
Number of unique OTUs & 1 & 3 & 5 & 2 & 11 \\
\hline
\end{tabular}

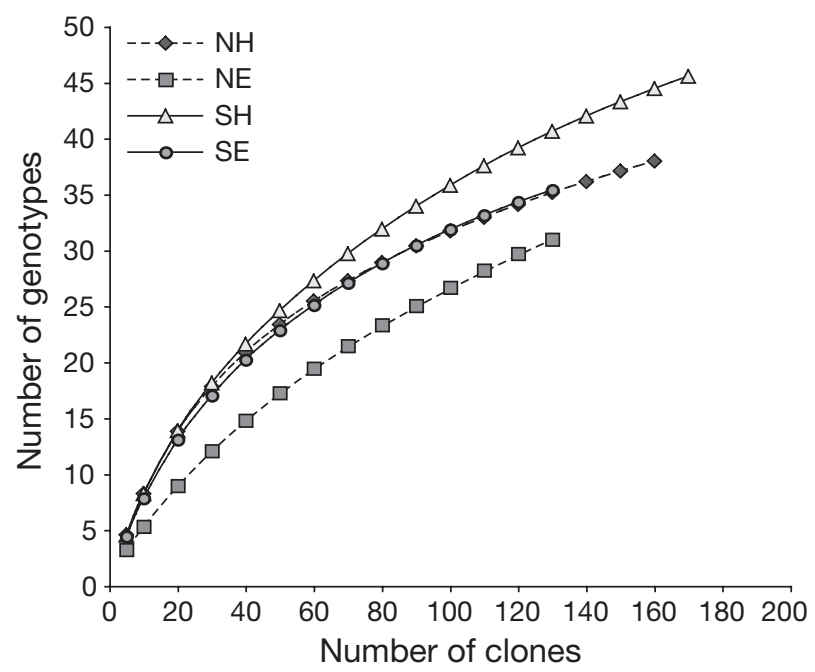

Fig. 1. Rarefaction curves for the 4 clone libraries. $\mathrm{NH}=$ north hypolimnion, $\mathrm{NE}=$ north epilimnion, $\mathrm{SH}=$ south hypolimnion, $\mathrm{SE}=$ south epilimnion of these OTUs were presumed chimera sequences, resulting in 61 remaining OTUs. The number of detected OTUs (Table 1) was similar to studies from other freshwater environments that had a comparable sampling effort (e.g. Eiler \& Bertilsson 2004). Of the 61 OTUs, 47 were sequenced, which corresponded to about $90 \%$ of the clones that were screened. The percentage of unsequenced clones was slightly higher in the epilimnion (14\% in both north and south) than in the hypolimnion $(5 \%$ in the north and $9 \%$ in the south).

Sequenced clones were identified as belonging to the Actinobacteria, Bacteroidetes, Chloroflexi, Cyanobacteria, Firmicutes, Acidobacteria, Verrucomicrobia, OP5, Chlorobi, and Planctomycetes divisions and the Alpha-, Beta-, Gamma- and Deltaproteobacteria subdivisions. The contribution of the different bacterial divisions and subdivisions to the sequenced OTUs is shown in Table 2. The phylogenetic relationships between the sequences derived from this study and database sequences are shown in Fig. 2.

The bacterial groups that were most represented in the clone library were the Cyanobacteria, Proteobacteria and Chloroflexi. The Cyanobacteria, represented by only 1 Synechococcus 6b cluster OTU (Robertson et al. 2001), were mainly observed in the 2 epilimnetic clone libraries and dominated in the epilimnion in the north of the lake. The Proteobacteria and Chloroflexi were most important in the hypolimnion and in the epilimnion in the south of the lake. The Gammaproteobacteria were the dominant subdivision of the Proteobacteria and were most important in the hypolimnion and in the epilimnion in the south. The Gammaproteobacteria OTUs mainly belonged to the Pseudomonadales, with 2 OTUs closely related to Pseudomonas stutzeri and 3 OTUs to the genus Acinetobacter. Betaproteobacteria had a comparable contribution to all 4 clone libraries. Three OTUs clustered together with genotypes related to the Alcaligenes. One OTU was closely related to the microaerophilic Aquabacterium citratiphilum frequently observed in drinking water systems. The Alphaproteobacteria were only abundant in the clone library of the hypolimnion in the north of the lake. The observed OTUs were closely related to Rhodobacter blasticus, Sphingomonas koreensis and Methylobacterium radiotolerans. The Deltaproteobacteria were a minor group, mainly occurring in the hypolimnetic clone libraries, with sequences clustering together with the strictly anaerobic genera Desulfobacca and Desulfomonile. Of the 7 OTUs identified as belonging to the phylum Chloroflexi, 3 OTUs belonged to the class Anaerolineae, 1 to the Dehalococcoidetes and 3 fell outside the classes defined by Hugenholtz \& Stackebrandt (2004). Actinobacteria were mainly 
Table 2. Percentage (\%) contribution of different bacterial divisions and subdivisions and of OTUs previously detected in freshwater (FW) environments to the clone libraries (see text for further details). Abbreviations as in Table 1

\begin{tabular}{|lccccc|}
\hline Bacterial group & $\mathrm{NH}$ & $\mathrm{NE}$ & $\mathrm{SH}$ & $\mathrm{SE}$ & Sum \\
\hline Actinobacteria & 4.6 & 3.6 & 16.6 & 17.1 & 10.6 \\
Alphaproteobacteria & 8.6 & 1.8 & 1.3 & 1.7 & 3.5 \\
Betaproteobacteria & 7.9 & 6.3 & 3.2 & 9.4 & 6.5 \\
Gammaproteobacteria & 28.3 & 6.3 & 15.3 & 19.7 & 18.1 \\
Deltaproteobacteria & 2.0 & 0.0 & 2.5 & 0.9 & 1.5 \\
Bacteroidetes & 11.2 & 11.7 & 3.2 & 8.5 & 8.4 \\
Chloroflexi & 17.8 & 4.5 & 39.5 & 12.8 & 20.3 \\
Cyanobacteria & 3.9 & 61.3 & 0.6 & 22.2 & 18.8 \\
Verrucobicrobia & 2.0 & 0.0 & 3.2 & 0.9 & 1.7 \\
Firmicutes & 0.0 & 0.0 & 0.6 & 0.0 & 0.2 \\
Fibrobacteres & 0.0 & 0.0 & 0.6 & 0.0 & 0.2 \\
Chlorobi & 8.6 & 0.0 & 0.0 & 0.0 & 2.4 \\
(green sulfur bacteria) & & & & & \\
Planktomycetes & 3.9 & 2.7 & 9.6 & 5.1 & 5.6 \\
OP5 & 0.7 & 0.9 & 2.5 & 0.9 & 1.3 \\
Sister group & 0.7 & 0.9 & 1.3 & 0.9 & 0.9 \\
$\quad$ Deferribacteres (TK-SH21) & & & & & \\
FW cluster & 21.1 & 77.5 & 5.7 & 47.0 & 33.9 \\
FW non-cluster & 21.7 & 7.2 & 43.3 & 18.8 & 24.4 \\
Non-FW & 57.2 & 15.3 & 51.0 & 34.2 & 41.7 \\
\hline
\end{tabular}

observed in the south of the lake. Five out of 8 OTUs, including those belonging to the freshwater clusters acIV-A (Warnecke et al. 2004) and Urk0-14 (Zwart et al. 2002), were related to Microthrix parvicella. Bacteroidetes were found in the epilimnion at both stations and in the hypolimnion in the north. Planctomycetes were observed at low densities in all samples. The remaining bacterial groups were only sporadically detected in the clone libraries. Acidobacteria and Firmicutes were only detected in the hypolimnion in the south, Chlorobi (anoxygenic phototrophic bacteria) were found exclusively in the hypolimnion in the north, Verrucomicrobia were observed in the hypolimnion at both stations and the epilimnion in the south. One OTU (TK-SH21) clustered outside of known clusters and had a low (81\%) sequence similarity to the closest cultivated bacterium Chrysiogenes arsenatis.

Based on the phylogenetic trees (Fig. 2) we discerned 3 groups (Table 2): (1) sequences closely related to typical freshwater clusters (Bahr et al. 1996, Hiorns et al. 1997, Methe et al. 1998, Bosshard et al. 2000, Glöckner et al. 2000, Urbach et al. 2001, Zwart et al. 2002, Eiler \& Bertilsson 2004, Van der Gucht et al. 2005); (2) sequences with high similarities to isolates from freshwater environments, but clustering together with genotypes isolated mainly from other environments; and (3) sequences that have not been observed in freshwater environments and are not closely related to typical freshwater genotypes.
Ten OTUs were considered to belong to known clusters of freshwater bacteria. Sequences belonging to typical freshwater clusters were observed for the Actinobacteria (acIV-A and Urk-14, Fig. 2A), Cyanobacteria (s6b, Fig. 2G) and for Betaproteobacteria (Fig. 2C) and Bacteroidetes sequences (Fig. 2E) clustering together with sequences obtained by Eiler \& Bertilsson (2004). Fourteen OTUs clustered together with sequences that have been reported from freshwater environments, but belonged to clusters that also contained representatives from marine and soil environments. Twentyfour OTUs were not related to sequences reported from freshwater environments. The highest contribution to the clone libraries of these genotypes that have not previously been reported from freshwater environments was found in the hypolimnion and in the epilimnion in the south of the lake (Table 2).

\section{DISCUSSION}

We studied the bacterial community composition at 4 contrasting locations in Lake Tanganyika using clone library analysis. Clone libraries were constructed using standard techniques that previously have been applied in many other freshwater systems (Zwart et al. 2002, Van der Gucht et al. 2005). The clone library approach to study bacterial communities is known to have several limitations. A first limitation is that some genotypes may be preferentially under- or overrepresented due to differences in DNA extraction efficiency, primer bias or preferential PCR amplification (e.g. von Wintzingerode et al. 1997). The fact that such bias also occurred in our study is illustrated by the cyanobacterial OTU identified as Synechococcus sp. The contribution (up to $61 \%$ ) of this picocyanobacterium to the clone libraries was much higher than its contribution to total bacterial abundance estimated from epifluorescence counts (e.g. up to $6 \times 10^{5}$ picocyanobacteria $\mathrm{ml}^{-1}$ [Vuorio et al. 2003] vs. $3 \times 10^{6}$ heterotrophic bacteria $\mathrm{ml}^{-1}$ [De Wever et al. 2005]), i.e. ca. $20 \%$. A second limitation is that the method is relatively labour intensive, which limits the number of samples that can be analyzed per study and the number of clones that can be analyzed per sample. The information yielded by a clone library study is, therefore, often optimized by a careful selection of the samples to be analyzed. In this study, the 4 samples analyzed were representative of the epi- and hypolimnion of the 2 major basins of Lake 


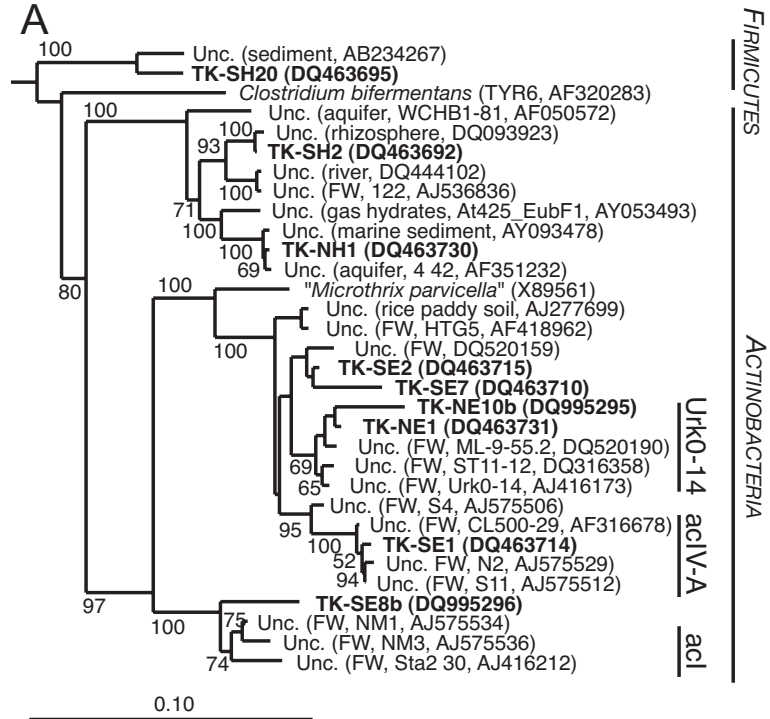

B

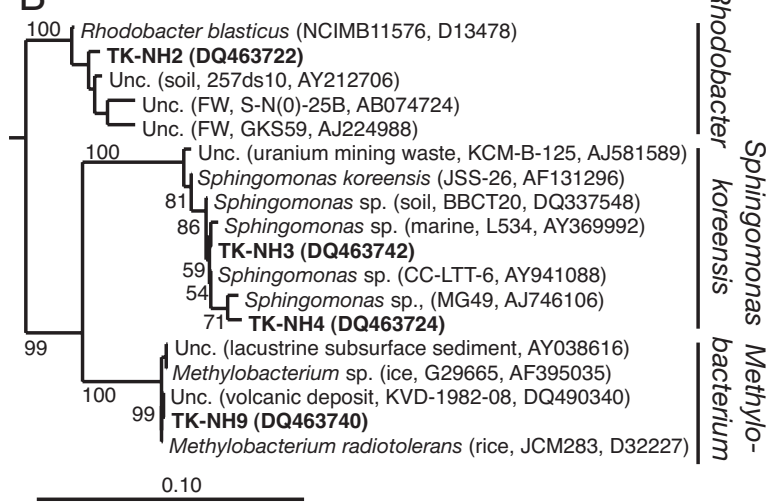

C

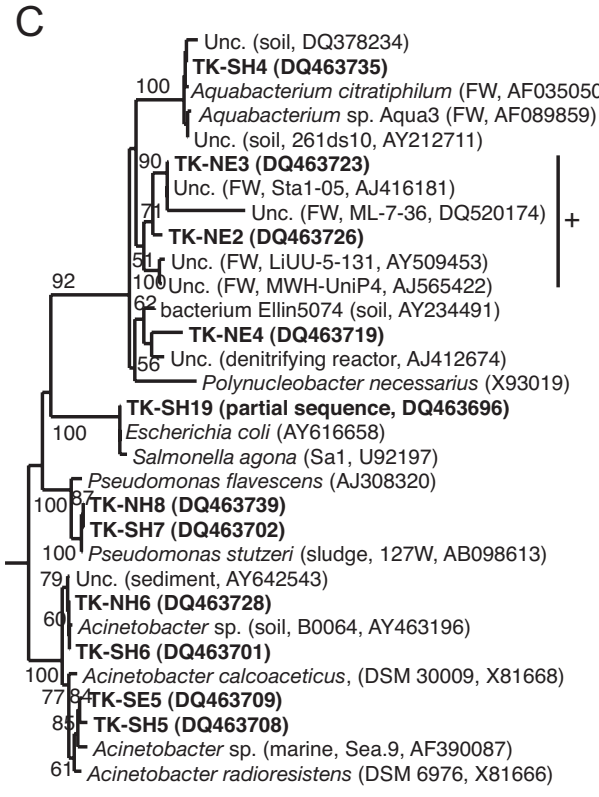

0.10

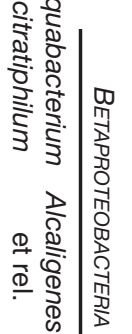
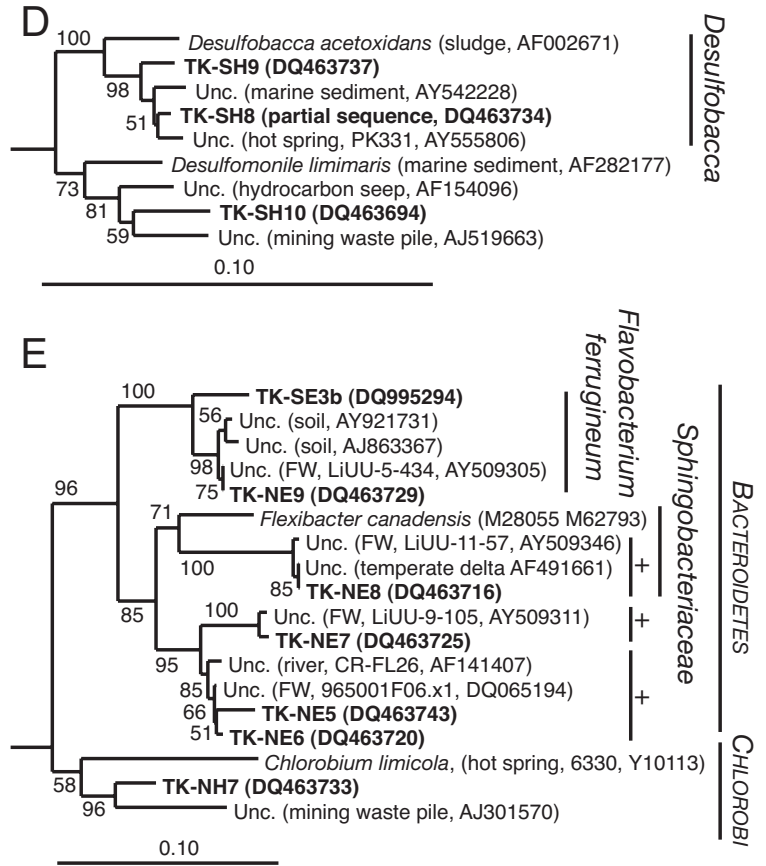

F 79 Unc. (waste water, AY239578)

77 TK-SH15 (DQ463704)

57 Unc. (tidal sediment, AY304372)

57 [ Unc. (tidal sediment, AY304372) TK-SH 18 (DO gas hy

TK-SH18 (DQ463738)
Unc. (marine gas hydrates, SHA 20, AJ306742)

Unc. (thermal spring, O1aA2, AY193182)

100 Unc. (sea mud vulcano, AY592385)

Unc. (marine gas hydrates, AY542237)

Dehalococcoides sp. (marine, BHI80 15, AJ431246)

$95-$ Unc. (FW sediment, AM086103)

- TK-SH17 (DQ463698)

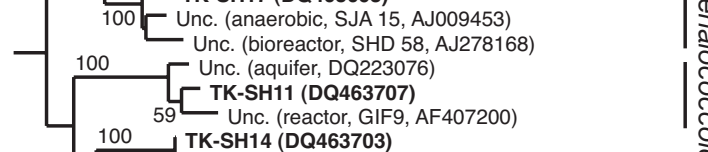

100 TK-SH14 (DQ463703)

TK-SH14 (DQ463703)
TK-SH12 (DQ463718)

63 TK-SH13 (DQ463736)

96 Unc. (bioreactor, SHA 26, AJ306743)

0.10

G

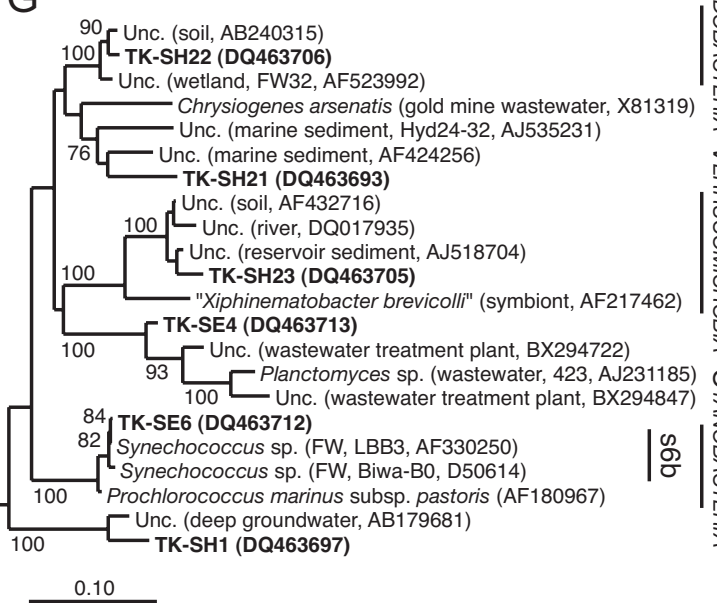


Fig. 2. Maximum likelihood tree showing phylogenetic relationship between sequenced genotypes, their closest matches during a BLAST search and relevant cluster representatives from studies of Glöckner et al. (2000), Zwart et al. (2002), Eiler \& Bertilsson (2004) and Warnecke et al. (2004). Bootstrap percentages shown at the nodes were calculated using maximum parsimony; only bootstrap support of $50 \%$ and more are show in the trees. Bacterial subdivisions are indicated using small capital letters. Original environment, clone or strain name and GenBank accession numbers are indicated in parentheses. Unc. $=$ uncultured, FW = genotypes isolated from freshwater environments. Freshwater clusters: Urk0-14, acIV-A, s6b and those designated with + are considered as belonging to a FW cluster. A = Actinobacteria, B = Alphaproteobacteria, C = Beta- and Gammaproteobacteria, ${ }^{*}$ Citrobacter-Escherichia-Salmonella-Shigella group, D = Deltaproteobacteria, $\mathrm{E}=$ Bacteroidetes, $\mathrm{F}=$ Chloroflexi, $\mathrm{G}=$ remaining groups

Tanganyika and these samples were collected at the time when these 2 major basins are most clearly differentiated, which is when upwelling of deep water occurs in the southern basin. Despite their limitations, clone library studies have revealed remarkably similar bacterial communities in freshwater systems from around the globe, with a fairly constant relative importance of major bacterial groups and a recurrence of genotypes from so-called typical freshwater bacterial clusters (e.g. Nold \& Zwart 1998, Zwart et al. 2002). Although the methodology and sampling effort in this study was comparable with many previous freshwater studies, the bacterial community observed in Lake Tanganyika differed in 2 major aspects from communities observed in many previous freshwater studies. First, the clone libraries had a high contribution of Gammaproteobacteria and Chloroflexi and, second, many genotypes from typical freshwater clusters were not detected.

The predominance of Gammaproteobacteria and Chloroflexi is in contrast to many previous freshwater studies, where Alpha- and Betaproteobacteria, Actinobacteria and Bacteroidetes tended to be the major groups and Chloroflexi and Gammaproteobacteria were usually represented by few clones (Bahr et al. 1996, Hiorns et al. 1997, Methe et al. 1998, Bosshard et al. 2000, Glöckner et al. 2000, Urbach et al. 2001, Zwart et al. 2002, Eiler \& Bertilsson 2004, Van der Gucht et al. 2005). The Gammaproteobacteria subdivision and Chloroflexi division were particularly important in the hypolimnetic clone libraries. Their prevalence, therefore, may be linked to the permanent dark and anoxic conditions in the hypolimnion of the lake. The detected Gammaproteobacteria and Chloroflexi seem to be adapted to these conditions. The Gammaproteobacterium genus, Pseudomonas, is known as a strong denitrifyer contributing to the phosphate uptake in the anoxic zone (Atkinson et al. 2001). A species belonging to the genus Acinetobacter has been shown to adapt rapidly to both anoxic and oxic conditions (Zafiri et al. 1999). Both species are well known from activated sludge, where they are thought to be important for phosphate removal (e.g. Bond et al. 1995). The observed OTUs from the Chloroflexi division did not belong to the class Chloroflexi (known for its photo- trophic representatives). Instead they belonged to the anaerobic classes Anaerolineae and Dehalococcoidetes, although they were only distantly related to cultivated representatives of these classes. The Anaerolineae are a group of physiologically diverse filamentous chemo-organotrophic bacteria (Yamada et al. 2006). The Dehalococcoidetes are a group of widely distributed bacteria that includes species that perform reductive dechlorination under anaerobic conditions (Hugenholtz \& Stackebrandt 2004).

An important fraction of the genotypes detected in the anoxic hypolimnetic samples belonged to strictly aerobic groups, including representatives of the Alpha- and Betaproteobacteria and Bacteroidetes. Under anoxic conditions, these bacteria are known to be able to just survive (e.g. methanotrophs in anoxic condition, Roslev \& King 1996) or perform at a low level of fermentative growth (e.g. aerobic denitrifiers, Jorgensen \& Tiedje 1993). This may indicate that some of the genotypes detected in the clone libraries were largely inactive.

In Lake Tanganyika, Gammaproteobacteria and Chloroflexi clones were not only very abundant in the anoxic hypolimnion, but were also relatively common in the clone library from the epilimnion in the south of the lake. The epilimnion in the south also shared other genotypes with the hypolimnetic clone libraries, including members of the Verrucomicrobia and Deltaproteobacteria. The similarity of the BCC in the epilimnion in the south of the lake with that of the hypolimnion was also noted in a DGGE survey of BCC that had a higher spatial resolution than the present study (De Wever et al. 2005). This similarity was probably related to the upwelling of deep water in the south of the lake, which is especially pronounced during the dry season when this study was carried out (Plisnier et al. 1999). Upwelling of deep water may result in the import of deep-water bacteria to surface waters and may influence BCC in the epilimnion. While these hypolimnetic bacteria are not necessarily adapted to grow under aerobic conditions in the hypolimnion (e.g. facultative anaerobic bacteria), they may nevertheless influence BCC through mass effects. In a study of Swedish lakes, Lindström et al. (2006) observed that bacteria imported into lakes from the watershed signif- 
icantly influenced BCC in the lakes through mass effects, even in lakes with a water retention time of up to $200 \mathrm{~d}$. The influence of the upwelling may be indirect due to the advection of nutrients enhancing the growth of these bacteria. Additional sampling during the rainy season, when no upwelling occurs in the south of the lake, is required to confirm whether the differences between both basins are due to upwelling or are related to other limnological differences.

Another striking feature of the clone libraries from Lake Tanganyika was the low contribution of bacteria belonging to the typical freshwater clusters. The existence of such clusters of bacteria that are widespread and common in many freshwater ecosystems has been proposed by Glöckner et al. (2000) and Zwart et al. (2002) and several more recent studies have confirmed the existence of such typical freshwater bacteria (e.g. Hahn 2003, Eiler \& Bertilsson 2004, Warnecke et al. 2004, Van der Gucht et al. 2005). About $50 \%$ of the OTUs detected in Lake Tanganyika were not closely related to genotypes previously detected in freshwater environments. Some bacterial clusters commonly found in freshwater environments (e.g. ACK4, LD12, Sta2-30) were not detected in the Lake Tanganyika clone libraries. Members of these genotypes were not expected in the hypolimnetic clone libraries as the characterization of these freshwater clusters was based mainly on studies from oxygenated freshwater systems. However, these clusters were also not encountered in the 2 clone libraries from the oxic epilimnion. These findings point to an atypical bacterial community in Lake Tanganyika compared with previously studied freshwater systems.

The oligotrophic nature of the lake does not seem to offer an explanation as the BCC has previously been studied in several other oligotrophic lakes, including Crater Lake (Urbach et al. 2001), Toolik Lake (Bahr et al. 1996), lakes from the Adirondack Mountains (Hiorns et al. 1997), Lake Baikal (Bel'kova et al. 2003) and Lake Gossenkölle (Glöckner et al. 2000). Lake Tanganyika is also known for its high $\mathrm{pH}$. The $\mathrm{pH}$ is known to influence $\mathrm{BCC}$ and the presence of certain typical freshwater clusters (Stepanauskas et al. 2003, Lindström et al. 2005). The low contribution of typical freshwater clusters to the epilimnetic clone libraries may also be due to the high contribution of hypolimnetic bacteria to the clone libraries from the epilimnion (see previous discussion). Temperature is known to influence BCC (Lindström et al. 2005); thus, the unusual BCC in the epilimnion (particularly in the south) of Lake Tanganyika may be due to its tropical location. Tropical lakes generally receive a high amount of solar irradiance resulting in reduced annual variation and high minimum water temperatures (Lewis 1987). So far, most studies on BCC in freshwater ecosystems focused on temperate ecosystems and, to our knowledge, no comparable clone library studies from tropical systems are currently available. Lake Tanganyika is also well known for its endemic species of fish, which have evolved during its ancient history. Possibly, the lake's ancient history also allowed for the development of a unique microbial community, especially in the huge volume of permanently anoxic water. In contrast to multicellular organisms, however, microorganisms are often considered to have global distribution (Fenchel et al. 1997). This seems to be confirmed by studies in freshwater (Zwart et al. 1998a) and marine (Mullins et al. 1995) ecosystems, where almost identical 16S rRNA genes have been found at distant locations. Although conclusions from a single gene should be made with caution, several recent studies found more localized distribution patterns for various microorganisms (e.g. Martiny et al. 2006, Pommier et al. 2007). Whether this is also the case for the bacterioplankton of Lake Tanganyika needs to be evaluated by comparison with other tropical freshwater environments.

Acknowledgements. This study was carried out in the framework of the CLIMLAKE project (EV/02) (Climate Variability as Recorded in Lake Tanganyika), which is supported by the Federal Science Policy Office, Belgium. A.D.W. received support from the Institute for the Promotion of Innovation through Science and Technology in Flanders (IWT). K.M. is a postdoctoral fellow from the Flemish Fund for Scientific Research. We thank I. Kimirei, L. Makasa and P. Isumbisho for help with onboard analyses, C. Cocquyt for taking genetic samples and for the countless hours of filtration work, J.-P. Descy and P.-D. Plisnier for the cruise organisation together with Dr. B. Wherli and C. Dinkel (EAWAG, Switzerland) and the Nyanza Project (NSF-ATM-9619458, Prof. A. Cohen) for providing necessary equipment. We also thank the anonymous reviewers for their valuable comments.

\section{LITERATURE CITED}

Altschul SF, Madden TL, Schäffer AA, Zhang JH, Zhang Z, Miller W, Lipman DJ (1997) Gapped BLAST and PSIBLAST: a new generation of protein database search programs. Nucleic Acids Res 25:3389-3402

Atkinson BW, Mudaly DD, Bux F (2001) Contribution of Pseudomonas spp. to phosphorus uptake in the anoxic zone of an anaerobic anoxic-aerobic continuous activated sludge system. Water Sci Technol 43:139-146

Bahr M, Hobbie JE, Sogin ML (1996) Bacterial diversity in an arctic lake: a freshwater SAR11 cluster. Aquat Microb Ecol 11:271-277

Bel'kova NL, Parfenova VV, Kostornova TY, Denisova LY, Zaichikov EF (2003) Microbial biodiversity in the water of Lake Baikal. Microbiology 72:203-212

Bond PL, Hugenholtz P, Keller J, Blackall LL (1995) Bacterial community structures of phosphate-removing and nonphosphate-removing activated sludges from sequencing batch reactors. Appl Environ Microbiol 61:1910-1916 
Bosshard PP, Santini Y, Gruter D, Stettler R, Bachofen R (2000) Bacterial diversity and community composition in the chemocline of the meromictic alpine Lake Cadagno as revealed by $16 \mathrm{~S}$ rDNA analysis. FEMS Microbiol Ecol 31:173-182

Chao A (1984) Nonparametric-estimation of the number of classes in a population. Scand J Stat 11:265-270

Crump BC, Armbrust EV, Baross JA (1999) Phylogenetic analysis of particle-attached and free-living bacterial communities in the Columbia River, its estuary, and the adjacent coastal ocean. Appl Environ Microbiol 65:3192-3204

De Wever A, Muylaert K, Van der Gucht K, Pirlot S and others (2005) Bacterial community composition in Lake Tanganyika: vertical and horizontal heterogeneity. Appl Environ Microbiol 71:5029-5037

De Wever A, Muylaert K, Cocquyt C, Van Wichelen J, Plisnier PD, Vyverman W (2007) Seasonal and spatial variability in the abundance of auto- and heterotrophic plankton in Lake Tanganyika. Fundam Appl Limnol (Arch Hydrobiol) 170: 49-63

Edmond JM, Stallard RF, Craig H, Craig V, Weiss RF, Coulter GW (1993) Nutrient chemistry of the water column of Lake Tanganyika. Limnol Oceanogr 38:725-738

Edwards U, Rogall T, Blocker H, Emde M, Bottger EC (1989) Isolation and direct complete nucleotide determination of entire genes - characterization of a gene coding for 16Sribosomal RNA. Nucleic Acids Res 17:7843-7853

Eiler A, Bertilsson S (2004) Composition of freshwater bacterial communities associated with cyanobacterial blooms in four Swedish lakes. Environ Microbiol 6:1228-1243

Felsenstein J (1981) Evolutionary trees from DNA-sequences a maximum-likelihood approach. J Mol Evol 17: 368-376

Fenchel T, Esteban GF, Finlay BJ (1997) Local versus global diversity of microorganisms: cryptic diversity of ciliated protozoa. Oikos 80:220-225

- Glöckner FO, Zaichikov E, Belkova N, Denissova L, Pernthaler J, Pernthaler A, Amann R (2000) Comparative 16s rRNA analysis of lake bacterioplankton reveals globally distributed phylogenetic clusters including an abundant group of Actinobacteria. Appl Environ Microbiol 66: 5053-5065

Good IL (1953) The population frequencies of species and the estimation of population parameters. Biometrika 40: 237-264

> Hahn MW (2003) Isolation of strains belonging to the cosmopolitan Polynucleobacter necessarius cluster from freshwater habitats located in three climatic zones. Appl Environ Microbiol 69:5248-5254

Hiorns WD, Methe BA, Nierzwicki-Bauer SA, Zehr JP (1997) Bacterial diversity in Adirondack mountain lakes as revealed by $16 \mathrm{~S}$ rRNA gene sequences. Appl Environ Microbiol 63:2957-2960

Hugenholtz P, Stackebrandt E (2004) Reclassification of Sphaerobacter thermophilus from the subclass Sphaerobacteridae in the phylum Actinobacteria to the class Thermomicrobia (emended description) in the phylum Chloroflexi (emended description). Int J Syst Evol Microbiol 54:2049-2051

> Jorgensen KS, Tiedje JM (1993) Survival of denitrifiers in nitrate-free, anaerobic environments. Appl Environ Microbiol 59:3297-3305

Konopka A, Bercot T, Nakatsu C (1999) Bacterioplankton community diversity in a series of thermally stratified lakes. Microb Ecol 38:126-135

Lane DJ (1991) 16S/23S rRNA sequencing. In: Stackebrandt E, Goodfellow M (eds) Sequencing techniques in bacterial systematics. Wiley, London, p 115-174
Lewis WM (1987) Tropical limnology. Annu Rev Ecol Syst 18:159-184

Lindström ES, Kamst-Van Agterveld MP, Zwart G (2005) Distribution of typical freshwater bacterial groups is associated with $\mathrm{pH}$, temperature, and lake water retention time. Appl Environ Microbiol 71:8201-8206

Lindström ES, Forslund M, Algesten G, Bergstrom AK (2006) External control of bacterial community structure in lakes. Limnol Oceanogr 51:339-342

Ludwig W, Strunk O, Westram R, Richter L and others (2004) Arb: a software environment for sequence data. Nucleic Acids Res 32:1363-1371

Martiny JBH, Bohannan BJM, Brown JH, Colwell RK and others (2006) Microbial biogeography: putting microorganisms on the map. Nat Rev Microbiol 4:102-112

Methe BA, Hiorns WD, Zehr JP (1998) Contrasts between marine and freshwater bacterial community composition: analyses of communities in Lake George and six other Adirondack lakes. Limnol Oceanogr 43:368-374

Mullins TD, Britschgi TB, Krest RL, Giovannoni SJ (1995) Genetic comparisons reveal the same unknown bacterial lineages in Atlantic and Pacific bacterioplankton communities. Limnol Oceanogr 40:148-158

Nold SC, Zwart G (1998) Patterns and governing forces in aquatic microbial comunities. Aquat Ecol 32:17-35

Plisnier PD, Chitamwebwa D, Mwape L, Tshibangu K, Langenberg V, Coenen E (1999) Limnological annual cycle inferred from physical-chemical fluctuations at three stations of Lake Tanganyika. Hydrobiologia 407:45-58

Pommier T, Canback B, Riemann L, Bostrom KH and others (2007) Global patterns of diversity and community structure in marine bacterioplankton. Mol Ecol 16:867-880

Robertson BR, Tezuka N, Watanabe MM (2001) Phylogenetic analyses of Synechococcus strains (Cyanobacteria) using sequences of $16 \mathrm{~S}$ rDNA and part of the phycocyanin operon reveal multiple evolutionary lines and reflect phycobilin content. Int J Syst Evol Microbiol 51: 861-871

Roslev P, King GM (1996) Regulation of methane oxidation in a freshwater wetland by water table changes and anoxia. FEMS Microbiol Ecol 19:105-115

Saitou N, Nei M (1987) The neighbor-joining method - a new method for reconstructing phylogenetic trees. Mol Biol Evol 4:406-425

Stepanauskas R, Moran MA, Bergamaschi BA, Hollibaugh JT (2003) Covariance of bacterioplankton composition and environmental variables in a temperate delta system. Aquat Microb Ecol 31:85-98

Urbach E, Vergin KL, Young L, Morse A, Larson GL, Giovannoni SJ (2001) Unusual bacterioplankton community structure in ultra-oligotrophic Crater Lake. Limnol Oceanogr 46:557-572

Van der Gucht K, Vandekerckhove T, Vloemans N, Cousin S and others (2005) Characterization of bacterial communities in four freshwater lakes differing in nutrient load and food web structure. FEMS Microbiol Ecol 53: 205-220

> von Wintzingerode F, Gobel UB, Stackebrandt E (1997) Determination of microbial diversity in environmental samples: pitfalls of PCR-based rRNA analysis. FEMS Microbiol Rev 21:213-229

> Vuorio K, Nuottajärvi M, Salonen K, Sarvala J (2003) Spatial distribution of phytoplankton and picocyanobacteria in Lake Tanganyika in March and April 1998. Aquat Ecosyst Health Manag 6:263-278

Warnecke F, Amann R, Pernthaler J (2004) Actinobacterial 16S rRNA genes from freshwater habitats cluster in four distinct lineages. Environ Microbiol 6:242-253 
Whitfield J (2005) Biogeography: Is everything everywhere? Science 310:960-961

Yamada T, Sekiguchi Y, Hanada S, Imachi H, Ohashi A, Harada H, Kamagata Y (2006) Anaerolinea thermolimosa sp. nov., Levilinea saccharolytica gen. nov., sp. nov. and Leptolinea tardivitalis gen. nov., so. nov., novel filamentous anaerobes, and description of the new classes Anaerolineae classis nov. and Caldilineae classis nov. in the bacterial phylum Chloroflexi. Int J Syst Evol Microbiol 56:1331-1340

Zafiri C, Kornaros M, Lyberatos G (1999) Kinetic modelling of biological phosphorus removal with a pure culture of Acinetobacter sp. under aerobic, anaerobic and transient operating conditions. Water Res 33:2769-2788

Editorial responsibility: Josep Gasol,

Barcelona, Spain
Zwart G, Hiorns WD, Methe BA, Van Agterveld MP and others (1998a) Nearly identical 16S rRNA sequences recovered from lakes in North America and Europe indicate the existence of clades of globally distributed freshwater bacteria. Syst Appl Microbiol 21:546-556

Zwart G, Huismans R, van Agterveld MP, Van de Peer Y and others (1998b) Divergent members of the bacterial division Verrucomicrobiales in a temperate freshwater lake. FEMS Microbiol Ecol 25:159-169

Zwart G, Crump BC, Agterveld M, Hagen F, Han SK (2002) Typical freshwater bacteria: an analysis of available 16S rRNA gene sequences from plankton of lakes and rivers. Aquat Microb Ecol 28:141-155

Submitted: October 31, 2006; Accepted: October 4, 2007 Proofs received from author(s): November 30, 2007 